\title{
Toxic and Repellent Characteristics of Some Plant Extracts used against Tribolium castaneum (Herbst) (Coleoptera: Tenebrionidae) Improve the Grain Quality of Stored Wheat
}

\author{
Bilal Atta ${ }^{1^{*}}$, Muhammad Rizwan ${ }^{1}$, Arshed Makhdoom Sabir ${ }^{1}$, Muhammad Dildar Gogi' ${ }^{2}$ Muhammad \\ Sabar ${ }^{1}$, Bakhtawar ${ }^{3}$, Faizan Ali $^{3}$ and Mehran Sarwar ${ }^{3}$
}

${ }^{1}$ Rice Research Institute, Kala Shah Kaku, Punjab, Pakistan; ${ }^{2}$ Department of Entomology, Faculty of Agriculture, University of Agriculture, Faisalabad, Punjab, Pakistan; ${ }^{3}$ Department of Entomology, Institute of Agricultural Sciences, University of the Punjab, Lahore, Pakistan.

Abstract | Tribolium castaneum (Herbst) (Coleoptera: Tenebrionidae) is one of the key insect pests of stored grains. Due to export regulations and zero-tolerance for alive insects in trade commodities, synthetic pesticides are often used to eliminate pest infestation in consignments. Phosphine is currently one and the only acceptable chemical used in stored grains, but due to their overuse, stored grain pests become resistant to this fumigant. There is, therefore, a great need to find alternatives. In this study insecticidal efficacy of different plant extracts viz. Ginger (Zingiber officinale), Neem (Azadirachta indica), Clove (Syzygium aromaticum) and Tobacco (Nicotiana tabacum) was compared against T. castaneum infesting stored wheat. The results have suggested that mortality and repellency in $T$. castaneum increased as the dose rate of crude plant extracts and exposure interval increased. The maximum mortality $(86.67 \%)$ was achieved with the highest dose of crude extract of $Z$. officinale ( $80 \mathrm{mg}$ per $7.5 \mathrm{~g}$ wheat) at 10 days exposure interval. Similarly, the highest dose of $Z$. officinale extract $(80 \mathrm{ml})$ was responsible to cause $100 \%$ repellency at 2 hours exposure interval. Results also suggested that grain damage and grain weight loss due to the feeding of $T$. castaneum decreased as the dose rate of crude plant extracts increased, while an increasing trend was found in these parameters with the increase in exposure interval. The maximum grain damage and grain weight loss $(10.27 \%$ and $0.346 \%$, respectively) were recorded at the lowest dose of $A$. indica crude extract at 10 days exposure interval. The result of Feeding Deterrence Index suggested that it increased as the dose rate of crude plant extracts increased while a decreased trend was found with the increase in exposure interval. The maximum feeding deterrence index $(86.48 \%)$ was recorded at the highest dose of $Z$. officinale crude extract at 5 days exposure interval. The results of this study supported the use of $Z$. officinale to reduce the population of $T$. castaneum by its toxic and repellent characteristics which ultimately improve the grain quality of stored wheat.

Received | March 01, 2020; Accepted | April 06, 2020; Published | May 15, 2020

*Correspondence | Bilal Atta, Rice Research Institute, Kala Shah Kaku, Punjab, Pakistan; Email: bilal.atta@aari.punjab.gov.pk

Citation | Atta, B., M. Rizwan, A.M. Sabir, M.D. Gogi, M. Sabar, Bakhtawar, F. Ali and M. Sarwar. 2020. Toxic and repellent characteristics of some plant extracts used against Tribolium castaneum (Herbst) (Coleoptera: Tenebrionidae) improve the grain quality of stored wheat. Journal of Innovative Sciences, 6(1): 1-11.

DOI | http://dx.doi.org/10.17582/journal.jis/2020/6.1.1.11

Keywords | Tribolium castaneum, Plant extracts, Toxicity, Repellency, Grain quality, Stored wheat

Abbreviation | DEI: Days Exposure Interval; HEI: Hours Exposure Interval; FDI: Feeding Deterrence Index; n: Insect population; T: Treated; Co: Control; Nc: Number of insects in control half; Nt: Number of insect in treated half; $\mathrm{N}_{\mathrm{d}}$ : Number of damaged grains; N: Total number of grains in sample; $\mathrm{W}_{\mathrm{u}}$ : Weight of undamaged grains; $\mathrm{N}_{\mathrm{u}}:$ Number of undamaged grains; $\mathrm{W}_{\mathrm{d}}$ : Weight of damaged grains; $\mathrm{N}_{\mathrm{d}}: \mathrm{Number}$ of damaged grains; C: Weight loss of control grains; T: Weight loss of treated grains; ANOVA: Analysis of Variance

June 2020 | Volume 6| Issue 1 | Page 1 


\section{Introduction}

Safe storage of grains and food products is a major problem in preventing damage from insect pests (Haq et al., 2005; Atta et al., 2020). Under favorable climatic and storage conditions, around $9 \%$ of global grain production is reduced through insect pests and mites (Adams and Schulten, 1978; Fields, 2006; Rahman et al., 2009). The red flour beetle, Tribolium castaneum (Herbst) (Coleoptera: Tenebrionidae), is one of the most important stored grain pests that have been reported to damage a variety of commodities such as grains (Shafique et al., 2006; Atta et al., 2020), flour (Campbell and Runnion, 2003; Naseri et al., 2017), peas (Pretheep-Kumar et al., 2007), beans (Abdullahi et al., 2018), nuts (Pires et al., 2017), dried fruits (Sarwar, 2015) and spices (Tripathi et al., 2009). Both larvae and adults feed on the grains destroyed by other pests (Mamun et al., 2009).

Preventive and curative control measures are in practice to control stored grains pests. Among these, highly toxic synthetic chemicals have been used for many years. However, these chemicals have some serious drawbacks on public health and the environment and insecticide resistance (Madkour et al., 2012). Therefore, it is necessary to find other sources that are readily available, affordable, less toxic to human and safe to the environment (Udo, 2005; Atta et al., 2019; Ayub et al., 2019a, 2019b, 2019c; Rizwan et al., 2019a, 2019b, 2019c, 2019d; Atta et al., 2020).

The use of plant material as traditional protectors of the stored products is an old practice that is used all over the world (Aslam et al., 2002). The protection of stored products usually involves the mixing of grains with the herbal mixture (Tapondjou et al., 2002). Efforts have been made in many countries to reduce the use of harmful pesticides through the use of native plant products, the implementation of integrated pest management methods, and the use of biodegradable products to protect stored grains (Khattach and Hameed, 1986). The control of stored grain pests using materials of natural origin is a topic of great importance today. Plants such as Azadirachta indica, Cassia fistula, Calotropis procera, Lantana camara and Chrysanthemum coronarium have shown insecticidal, antifeedant, repellant and growth-regulating properties to insects (Singh and Singh, 2005; Neoliya et al., 2007; Sankari and Narayanswamy, 2007). Such botanical products have several advantages over synthetic insecticides such as environmental safety, less hazardous, economic and easy availability (Gupta and Pathak, 2009; Tembo et al., 2018).

The present study was conducted to investigate the toxic and repellent characteristics of some plant extracts (Z. officinale, $A$. indica, S. aromaticum and $N$. tabacum) used against $T$. castaneum for the improvement of grain quality in stored wheat. The results could help devise environment-friendly management practices for the control of T. castaneum.

\section{Materials and Methods}

\subsection{Experimental site}

The study was conducted at the Entomology Laboratory, Rice Research Institute, Kala Shah Kaku, Punjab, Pakistan ( $31^{\circ} 43^{\prime} 17^{\prime \prime} \mathrm{N}$ and $\left.74^{\circ} 16^{\prime} 14^{\prime \prime} \mathrm{E}\right)$.

\subsection{Acquisition and rearing of tribolium castaneum}

The adults of $T$. castaneum were acquired from Akbari Grain Market Lahore, Pakistan (31.5807 ${ }^{\circ}$ N, $74.3256^{\circ}$ E) and were sub-cultured by rearing on synthetic food made from whole wheat flour and bakers' yeast with the proportion of 19:1 under laboratory conditions (Morgan et al., 2003; Amin et al., 2012; Qasim et al., 2013; Atta et al., 2020) of $28 \pm 2{ }^{\circ} \mathrm{C}, 60 \pm 5 \%$ R.H. and 12:12 D:L photoperiod (Shafique et al., 2006; Safavi and Mobki, 2012; Qasim et al., 2013; Perez-Mendoza et al., 2014; Sami et al., 2018; Atta et al., 2020).

\subsection{Plant materials}

Fresh leaves of $A$. indica, $Z$. officinale, $S$. aromaticum and $N$. tabacum were collected from the trees planted under the boundaries of Rice Research Institute, Kala Shah Kaku, Pakistan, to conduct the study.

\subsection{Preparation of plant extracts}

For the preparation of plant extracts, the fresh leaves of $A$. indica, Z. officinale, S. aromaticum and N. tabacum were washed sufficiently with distilled water. After drying under the shade, the leaves were ground to a fine powder with an electrical grinder. For investigating the toxic effect of these plant extracts, four different doses of plant powders were weighed $(20 \mathrm{mg}, 40 \mathrm{mg}$, $60 \mathrm{mg}$ and $80 \mathrm{mg}$ ) and placed these in conical flasks separately. For investigating the repellent effect of these plant extracts, plant powder $(10 \mathrm{~g})$ was placed in conical flasks $(250 \mathrm{ml})$ along with $100 \mathrm{ml}$ of distilled water and placed on heating $\left(60^{\circ} \mathrm{C}\right)$ and shake with a magnetic stirrer (AM4, Velp Scientifica, Italy) for

Journal of Innovative Sciences

June 2020 | Volume 6| Issue 1 | Page 2 
$6 \mathrm{hrs}$ to dissolve the leaf powder properly. The solid residues were removed using muslin cloths, and plant extracts were then filtered (Whatman No. 1). After evaporation by using a rotary evaporator at $60^{\circ} \mathrm{C}$ under vacuum, the dried plant extracts were brought to constant volume, using a hot air oven $\left(60^{\circ} \mathrm{C}\right)$. These extracts were stored under $4^{\circ} \mathrm{C}$ till used as a stock solution. Four concentrations of $A$. indica, $Z$. officinale, $S$. aromaticum and $N$. tabacum extracts were prepared separately $(20 \mathrm{ml}, 40 \mathrm{ml}, 60 \mathrm{ml}$ and $80 \mathrm{ml})$ by dilution with distilled water from this stock solution. For investigating the impact of plant extracts on grain quality, four different doses $(20 \mathrm{mg}, 40 \mathrm{mg}, 60 \mathrm{mg}$ and $80 \mathrm{mg}$ ) were prepared by following similar procedure was adopted in toxic effect investigation.

\subsection{Toxic characteristic of plant extracts against tribolium castaneum}

Wheat grains $(7.5 \mathrm{~g})$ were weighted and filled in plastic jars. Four concentrations of crude plant extracts (20, $40,60,80 \mathrm{mg}$ ) were mixed in wheat grains separately. Twenty adults of $T$. castaneum were collected from rearing jars with the help of aspirator and released in jars separately and covered with the muslin cloth. The experiment was replicated thrice and placed in a dark room to enhance the activity of $T$. castaneum. The mortality was corrected and calculated after 5 and 10 days according to the formula (Henderson and Tilton, 1995).

Corrected mortality $(\%)=\left(1-\frac{\mathrm{n} \text { in } \mathrm{C}_{0} \text { before treatment } \times \mathrm{n} \text { in T after treatment }}{\mathrm{n} \text { in } \mathrm{C}_{0} \text { after treatment } \times \mathrm{n} \text { in T before treatment }} \times 100\right.$

Where: $\mathrm{n}=$ Insect population; $\mathrm{T}=$ Treated; $\mathrm{Co}=\mathrm{Control}$

\subsection{Repellent characteristic of plant extracts against tribolium castaneum}

The test was started by taking filter paper cutting it according to the size of the Petri dish taken. Half of the filter paper dipped in four different doses of plant extracts separately for $5 \mathrm{~min}$ and the other half into distilled water. The experiment was replicated thrice. Twenty adults of $T$. castaneum were released in each replication in the center of the Petri dishes. The experiment was placed in a dark room to enhance the activity of $T$. castaneum. The data of repellency was recorded after 1 and 2 hrs by using the formula (Gillenwater and Mc Donald, 1975).

$$
\text { Repellency }(\%)=\frac{\mathrm{Nc}-\mathrm{Nt}}{\mathrm{Nc}+\mathrm{Nt}} \times 100
$$

Where: $\mathrm{Nc}=$ Number of insects in control half; $\mathrm{Nt}=$ Number of insect in treated half.

2.7 Assessment of grain quality parameters due to tribolium castaneum exposed to crude plant extracts

Wheat grains $(7.5 \mathrm{~g})$ were weighted, counted and filled in plastic jars. Four concentrations of crude plant extracts were mixed in wheat grains separately. Twenty adults of $T$. castaneum were collected from rearing jars with the help of aspirator and released in jars separately and covered with the muslin cloth. The experiment was replicated thrice and placed in a dark room to enhance the activity of $T$. castaneum. After 5 and 10 days, damaged and undamaged wheat grains were counted and recorded the data by using the formula (Atta et al., 2020).

$$
\text { Grain damage }(\%)=\frac{\mathrm{N}_{\mathrm{d}}}{\mathrm{N}} \times 100
$$

Where: $\mathrm{N}_{\mathrm{d}}=$ Number of damaged grains; $\mathrm{N}=$ Total number of grains in sample.

After 5 and 10 days, treated grains were weighed to check the weight loss in wheat grains and recorded the data by using the formula (Atta et al., 2020).

$$
\text { Grain weight loss }(\%)=\frac{\left(\mathrm{W}_{\mathrm{u}} \times \mathrm{N}_{\mathrm{d}}\right)-\left(\mathrm{W}_{\mathrm{d}} \times \mathrm{N}_{\mathrm{u}}\right)}{\mathrm{W}_{\mathrm{u}}\left(\mathrm{N}_{\mathrm{d}}+\mathrm{N}_{\mathrm{u}}\right)} \times 100
$$

Where: $\mathrm{W}_{\mathrm{u}}=$ Weight of undamaged grains; $\mathrm{N}_{\mathrm{u}}=$ Number of undamaged grains; $W_{d}=$ Weight of damaged grains; $\mathrm{N}_{d}=$ Number of damaged grains .

Feeding Deterrence Index (FDI) was calculated by using the formula (Brari and Kumar, 2019).

$$
\text { FDI }(\%)=\frac{\mathrm{C}-\mathrm{T}}{\mathrm{C}+\mathrm{T}} \times 100
$$

Where: $\mathrm{C}=$ Weight loss of control grains; $\mathrm{T}=$ Weight loss of treated grains.

\subsection{Statistical analysis}

Data was subjected to two-way analysis of variance (ANOVA) using statistical software Statistix ${ }^{\oplus}$ (Version 8.1). Treatment means were separated by Bonferroni test at $\alpha=0.05$. 


\section{Results and Discussion}

\subsection{Toxic characteristic of plant extracts against tribolium castaneum}

The main effects and interaction of various crude plant extracts and their doses are highly significant $(P<0.05)$ on percent mortality of $T$. castaneum at two different exposure intervals (Table 1 ).Percent morality of $T$. castaneum exposed to different crude extracts mixed in wheat grains was gradually increased as the exposure interval increased. The highest and lowest percent mortality $(55.83 \pm 2.17 \%$ and $29.17 \pm 1.65 \%)$ was recorded in $Z$. officinale and $A$. indica treated wheat after 10 DEI, respectively, while no mortality was recorded in control treatment at both exposure intervals. Crude extracts caused mortality with the trend of $Z$. officinale $<S$. aromaticum $<N$. tabacum $<A$. indica (Figure 1). A similar trend of increase in mortality was observed in the case of doses of crude extracts as in Figure 1. The highest dose $(80 \mathrm{mg}$ per $7.5 \mathrm{~g}$ wheat) and lowest dose $(20 \mathrm{mg}$ per $7.5 \mathrm{~g}$ wheat $)$ of crude extracts caused $51.33 \pm 6.37 \%$ and $15.33 \pm 2.43 \%$

Table 1: Main effects and interaction of various plant extracts and their doses in relation to mortality (\%) and repellency (\%) of Tribolium castaneum, and grain quality parameters (\%) due to Tribolium castaneum at different exposure intervals.

\begin{tabular}{|c|c|c|c|c|c|c|c|c|c|c|c|c|}
\hline \multirow[t]{3}{*}{ Factors } & \multirow[t]{3}{*}{ df } & \multicolumn{10}{|l|}{$F$ value } & \multirow[t]{3}{*}{$P$ value } \\
\hline & & \multicolumn{2}{|c|}{ Mortality (\%) } & \multicolumn{2}{|c|}{ Repellency (\%) } & \multicolumn{2}{|c|}{ Grain damage (\%) } & \multicolumn{2}{|c|}{$\begin{array}{l}\text { Grain weight loss } \\
(\%)\end{array}$} & \multicolumn{2}{|c|}{$\begin{array}{l}\text { Feeding Deter- } \\
\text { rence Index (\%) }\end{array}$} & \\
\hline & & $5 \mathrm{DEI}$ & $10 \mathrm{DEI}$ & $1 \mathrm{HEI}$ & $2 \mathrm{HEI}$ & $5 \mathrm{DEI}$ & $10 \mathrm{DEI}$ & 5 DEI & $10 \mathrm{DEI}$ & 5 DEI & 10 DEI & \\
\hline Plant extracts & $4^{\mathrm{a} / 59^{\mathrm{b}}}$ & $53.35^{* *}$ & $73.68^{* *}$ & $67.96^{* *+}$ & $113.78^{* *}$ & $1379.61^{* *}$ & $3160.79^{* *}$ & $748.00^{*}$ & $1461.76^{* *}$ & $820.10^{* *}$ & $335.32^{* *}$ & $<0.05$ \\
\hline Doses & $3^{\mathrm{a} / 59^{\mathrm{b}}}$ & $47.90^{* * *}$ & $47.93^{* * *}$ & $31.10^{* * *}$ & $30.62^{* *}$ & $292.17^{4 *}$ & $462.21^{* *}$ & $173.14^{* *}$ & $304.01^{* *}$ & $301.08^{* *}$ & $110.40^{* *}$ & $<0.05$ \\
\hline $\begin{array}{l}\text { Plant extracts } \\
\times \text { Doses }\end{array}$ & $12^{\mathrm{a}} / 59^{\mathrm{b}}$ & $3.19^{* *}$ & $3.54^{* *}$ & $2.54^{* * *}$ & $2.60^{* *}$ & $22.37^{* *}$ & $34.91^{*}$ & $14.67^{* *}$ & $19.88^{* *}$ & $19.86^{* *}$ & $7.84^{* *}$ & $<0.05$ \\
\hline
\end{tabular}

a:Treatment degree of freedom; ${ }^{\mathrm{b}}$ : Error degree of freedom; $d f$ degree of freedom; DEI: Days exposure interval; HEI: Hours exposure interval; ": highly significant at $\alpha<0.05$.

Table 2: Mortality (\%) and Repellency $(\%)($ Mean \pm SE, $n=3)$ of Tribolium castaneum exposed to various plant extracts and their doses mixed in wheat grains at different exposure intervals.

\begin{tabular}{lllllll}
\hline Plant ex- & \multicolumn{5}{l}{ Mortality (\%) } & \multicolumn{4}{l}{ Repellency (\%) } \\
\cline { 2 - 6 } tracts & $\begin{array}{l}\text { Doses (mg per } \\
7.5 \text { g wheat) }\end{array}$ & $5 \mathrm{DEI}$ & $\mathbf{1 0} \mathrm{DEI}$ & Doses $(\mathrm{ml})$ & $5 \mathrm{DEI}$ & $\mathbf{1 0} \mathrm{DEI}$ \\
\hline Zingiber & 20 & $23.33 \pm 5.09 \mathrm{CDEFGH}$ & $30.00 \pm 6.67 \mathrm{cdef}$ & 20 & $43.33 \pm 5.09 \mathrm{BCDEFG}$ & $70.00 \pm 6.67 \mathrm{abc}$ \\
officinale & 40 & $36.67 \pm 5.09 \mathrm{BCDEF}$ & $46.67 \pm 3.85 \mathrm{bcd}$ & 40 & $60.00 \pm 6.67 \mathrm{ABCD}$ & $73.33 \pm 5.09 \mathrm{abc}$ \\
& 60 & $50.00 \pm 6.67 \mathrm{ABC}$ & $60.00 \pm 6.67 \mathrm{ab}$ & 60 & $73.33 \pm 5.09 \mathrm{AB}$ & $100.00 \pm 0.00 \mathrm{a}$ \\
& 80 & $70.00 \pm 3.33 \mathrm{~A}$ & $86.67 \pm 5.09 \mathrm{a}$ & 80 & $86.67 \pm 5.09 \mathrm{~A}$ & $100.00 \pm 0.00 \mathrm{a}$ \\
Syzygium & 20 & $16.67 \pm 5.09 \mathrm{EFGH}$ & $23.33 \pm 5.09 \mathrm{defg}$ & 20 & $26.67 \pm 5.09 \mathrm{DEFGH}$ & $43.33 \pm 8.39 \mathrm{~cd}$ \\
aromaticum & 40 & $30.00 \pm 5.77 \mathrm{CDEFG}$ & $43.33 \pm 5.09 \mathrm{bcde}$ & 40 & $36.67 \pm 11.71 \mathrm{CDEFG}$ & $70.00 \pm 6.67 \mathrm{abc}$ \\
& 60 & $46.67 \pm 6.94 \mathrm{ABCD}$ & $50.00 \pm 6.67 \mathrm{bcd}$ & 60 & $70.00 \pm 6.67 \mathrm{ABC}$ & $86.67 \pm 5.09 \mathrm{ab}$ \\
& 80 & $63.33 \pm 8.39 \mathrm{AB}$ & $63.33 \pm 7.70 \mathrm{ab}$ & 80 & $76.67 \pm 5.09 \mathrm{AB}$ & $100.00 \pm 0.00 \mathrm{a}$ \\
Nicotiana & 20 & $10.00 \pm 3.33 \mathrm{FGH}$ & $16.67 \pm 1.92 \mathrm{efg}$ & 20 & $20.00 \pm 5.77 \mathrm{EFGH}$ & $26.67 \pm 6.94 \mathrm{de}$ \\
tabacum & 40 & $20.00 \pm 3.33 \mathrm{DEFGH}$ & $26.67 \pm 3.85 \mathrm{defg}$ & 40 & $26.67 \pm 8.39 \mathrm{DEFGH}$ & $53.33 \pm 10.18 \mathrm{bcd}$ \\
& 60 & $33.33 \pm 5.09 \mathrm{CDEF}$ & $40.00 \pm 6.67 \mathrm{bcde}$ & 60 & $46.67 \pm 8.39 \mathrm{BCDEF}$ & $63.33 \pm 6.94 \mathrm{bc}$ \\
& 80 & $46.67 \pm 6.94 \mathrm{ABCD}$ & $56.67 \pm 6.94 \mathrm{bc}$ & 80 & $56.67 \pm 8.39 \mathrm{ABCD}$ & $73.33 \pm 5.09 \mathrm{abc}$ \\
Azadirachta & 20 & $3.33 \pm 1.92 \mathrm{GH}$ & $6.67 \pm 1.92 \mathrm{fg}$ & 20 & $10.00 \pm 0.00 \mathrm{GH}$ & $23.33 \pm 5.09 \mathrm{de}$ \\
indica & 40 & $10.00 \pm 3.33 \mathrm{FGH}$ & $23.33 \pm 5.09 \mathrm{defg}$ & 40 & $13.33 \pm 5.09 \mathrm{FGH}$ & $40.00 \pm 6.67 \mathrm{~cd}$ \\
& 60 & $30.00 \pm 5.77 \mathrm{CDEFG}$ & $36.67 \pm 5.09 \mathrm{bcde}$ & 60 & $26.67 \pm 8.39 \mathrm{DEFGH}$ & $50.00 \pm 6.67 \mathrm{~cd}$ \\
& 80 & $43.33 \pm 3.85 \mathrm{ABCDE}$ & $50.00 \pm 3.33 \mathrm{bcd}$ & 80 & $50.00 \pm 6.67 \mathrm{BCDE}$ & $66.67 \pm \mathrm{abc}$ \\
Control & - & $0.00 \pm 0.00 \mathrm{H}$ & $0.00 \pm 0.00 \mathrm{~g}$ & - & $0.00 \pm 0.00 \mathrm{H}$ & $0.00 \pm 0.00 \mathrm{e}$ \\
\hline
\end{tabular}

DEI: Days exposure interval; HEI: Hours exposure interval; Means with different letters are significantly different $(P<0.05)$, Bonferroni test, comparisons across all treatments.

Journal of Innovative Sciences

June 2020 | Volume 6| Issue 1 | Page 4 
mortality, respectively after 10 DEI. Doses of crude extracts caused mortality with the trend of $80 \mathrm{mg}$ per $7.5 \mathrm{~g}$ wheat $<60 \mathrm{mg}$ per $7.5 \mathrm{~g}$ wheat $<40 \mathrm{mg}$ per $7.5 \mathrm{~g}$ wheat $<20 \mathrm{mg}$ per $7.5 \mathrm{~g}$ wheat (Figure 2). Percent mortality of T. castaneum in different doses $(20-80 \mathrm{mg}$ per $7.5 \mathrm{~g}$ wheat) of $Z$. officinale treated wheat grains ranged from $23.33-70.00 \%$ at 5 DEI and 30.00$86.67 \%$ at $10 \mathrm{DEI}$, S. aromaticum treated wheat grains ranged from $16.67-63.33 \%$ at 5 DEI and 23.33$63.33 \%$ at $10 \mathrm{DEI}, N$. tabacum treated wheat grains ranged from $10.00-46.67 \%$ at 5 DEI and 16.67$56.67 \%$ at $10 \mathrm{DEI}$, and $A$. indica treated wheat grains ranged from $3.33-43.33 \%$ at 5 DEI and $6.67-50.00 \%$ at 10 DEI (Table 2).

\subsection{Repellent characteristic of plant extracts against tribolium castaneum}

The main effects and interaction of various plant extracts and their doses are highly significant $(P<$ 0.05 ) on percent repellency of $T$. castaneum at two different exposure intervals (Table 1). The maximum number of $T$. castaneum showed repellent behavior to the control half, when half filter paper was exposed to different plant extracts and their doses. T. castaneum exposed to $Z$. officinale extract at the highest dose (80mg per $7.5 \mathrm{~g}$ wheat) showed maximum repellent behavior as compared to other extracts ( $S$. aromaticum, $N$. tabacum and $A$. indica) and doses (20mg, $40 \mathrm{mg}$ and $60 \mathrm{mg}$ per $7.5 \mathrm{~g}$ wheat) (Figure $3)$. Percent repellency of $T$. castaneum exposed to different plant extracts was gradually increased as the exposure interval increased. The highest and lowest percent repellency $(85.83 \pm 4.10 \%$ and $45.00 \pm 4.54 \%)$ was recorded in $Z$. officinale and $A$. indica treated wheat after $2 \mathrm{HEI}$, respectively, while no repellency was recorded in control treatment at both exposure intervals. Plant extracts caused repellency with the trend of $Z$. officinale $<S$. aromaticum $<N$. tabacum $<A$. indica (Figure 1). A similar trend of increase in repellency was observed in the case of doses of extracts as in Figure 1. The highest dose $(80 \mathrm{ml})$ and lowest dose $(20 \mathrm{ml})$ of extracts caused $68.00 \pm 8.19 \%$ and $32.67 \pm 5.19 \%$ repellency, respectively after 2 HEI. Doses of extracts caused repellency with the trend of $80 \mathrm{ml}<60 \mathrm{ml}<40 \mathrm{ml}<20 \mathrm{ml}$ (Figure 2). Percent repellency of $T$. castaneum in different doses $(20-80 \mathrm{ml})$ of $Z$. officinale extract ranged from $43.33-86.67 \%$ at $1 \mathrm{HEI}$ and $70.00-100.00 \%$ at 2 HEI, S. aromaticum extract ranged from 26.67$76.67 \%$ at $1 \mathrm{HEI}$ and $43.33-100.00 \%$ at $2 \mathrm{HEI}$,
N. tabacum extract ranged from $20.00-56.67 \%$ at $1 \mathrm{HEI}$ and $26.67-73.33 \%$ at $2 \mathrm{HEI}$, and $A$. indica extract ranged from $10.00-50.00 \%$ at $1 \mathrm{HEI}$ and $23.33-66.67 \%$ at 2 HEI (Table 2).

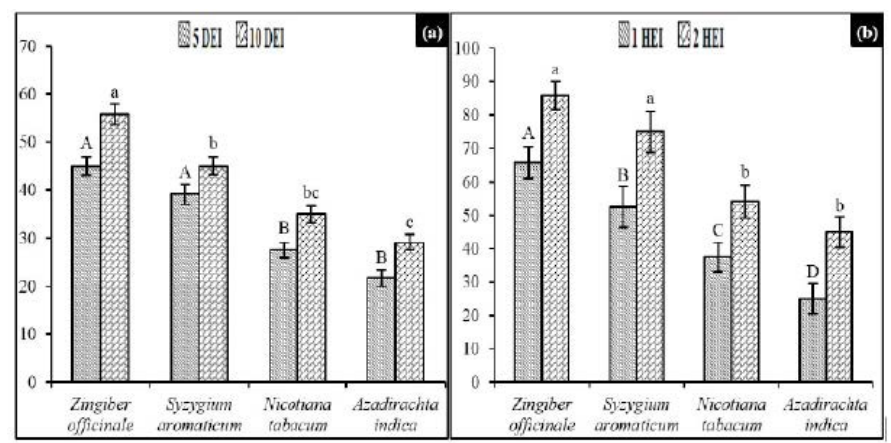

Figure 1: Mortality (\%) ${ }^{(a)}$ and Repellency (\%) ${ }^{(b)}$ (Mean $\pm \mathrm{SE}, n=3$ ) of Tribolium castaneum exposed to various plant extracts (Zingiber officinale, Syzygium aromaticum, Nicotiana tabacum and Azadirachta indica) at different exposure intervals. Plant extracts are on $x$-axis and measured variables are on $y$-axis. DEI $=$ Days exposure interval; HEI $=$ Hours exposure interval; Means with different letters are significantly different $(P<0.05)$, Bonferroni test, comparisons across all treatments.

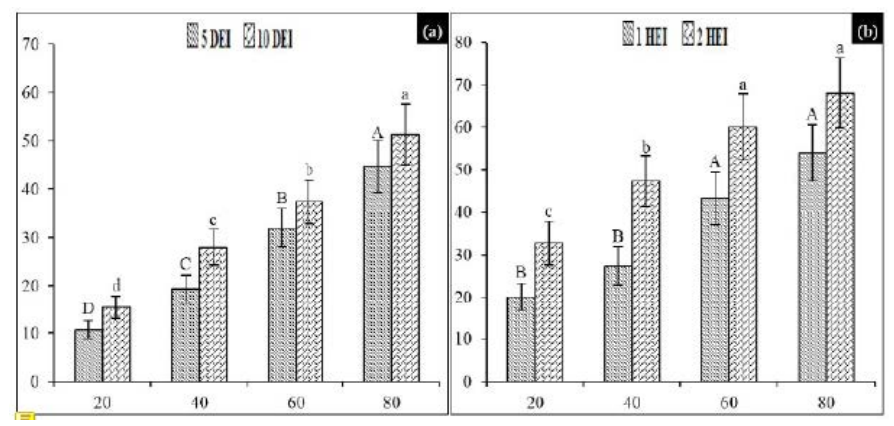

Figure 2: Mortality (\%) $)^{(\mathbf{a})}$ and Repellency (\%) ${ }^{(\mathrm{b})}$ (Mean \pm SE, $n=3$ ) of Tribolium castaneum exposed to various doses $(20 \mathrm{mg}, 40 \mathrm{mg}, 60 \mathrm{mg}$ and $80 \mathrm{mg}$ ) of plant extracts (Zingiber officinale, Syzygium aromaticum, Nicotiana tabacum and Azadirachta indica) at different exposure intervals. Extract doses are on $x$-axis and measured variables are on $y$-axis. DEI $=$ Days exposure interval; HEI $=$ Hours exposure interval; Means with different letters are significantly different $(P<0.05)$, Bonferroni test, comparisons across all treatments.

3.3 Assessment of grain quality parameters due to tribolium castaneum exposed to crude plant extracts

Grain damage (\%): The main effects and interaction of various crude plant extracts and their doses are highly significant $(P<0.05)$ on percent grain damage due to the $T$. castaneum at two different exposure 
intervals (Table 1). Percent grain damage due to the T. castaneum exposed to different crude extracts mixed in wheat grains was gradually increased as the exposure interval increased. The highest and lowest grain damage $(12.40 \pm 0.42 \%$ and $7.00 \pm 0.56 \%)$ was recorded in $A$. indica and $Z$. officinale treated wheat after 10 DEI, respectively, while grain damage in control treatment ranged from $15.33-18.13 \%$ at both exposure intervals. T. castaneum exposed to different crude extracts caused grain damage with the trend of $A$. indica $<N$. tabacum $<S$. aromaticum $<Z$. officinale (Figure 4). Grain damage due to T. castaneum decreased as the dose rate of crude plant extracts increased. The lowest dose $(20 \mathrm{mg}$ per $7.5 \mathrm{~g}$ wheat) and highest dose $(80 \mathrm{mg}$ per $7.5 \mathrm{~g}$ wheat) of crude extracts caused $13.31 \pm 0.63 \%$ and $9.97 \pm 1.00 \%$ grain damage, respectively after 10 DEI. Doses of crude extracts caused grain damage with the trend of $20 \mathrm{mg}$ per $7.5 \mathrm{~g}$ wheat $<40 \mathrm{mg}$ per $7.5 \mathrm{~g}$ wheat $<60 \mathrm{mg}$ per $7.5 \mathrm{~g}$ wheat $<80 \mathrm{mg}$ per $7.5 \mathrm{~g}$ wheat (Figure 5). Percent grain damage due to $T$. castaneum exposed to different doses (20-80mg per $7.5 \mathrm{~g}$ wheat) of $A$. indica treated wheat grains decreased from $12.80-8.93 \%$ at 5 DEI and 14.27$10.27 \%$ at $10 \mathrm{DEI}, N$. tabacum treated wheat grains decreased from $11.20-7.20 \%$ at 5 DEI and $12.67-$ $9.20 \%$ at $10 \mathrm{DEI}, S$. aromaticum treated wheat grains decreased from $9.60-5.07 \%$ at 5 DEI and $11.60-7.33 \%$ at $10 \mathrm{DEI}$, and $Z$. officinale treated wheat grains decreased from $8.27-2.53 \%$ at $5 \mathrm{DEI}$ and $9.87-4.93 \%$ at 10 DEI (Table 3).

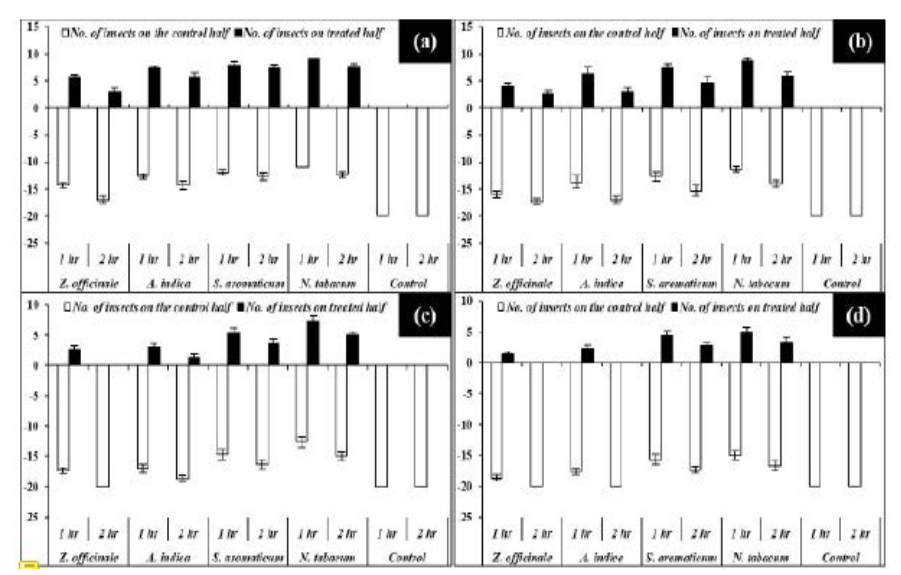

Figure 3: Repellent behavior of total number of Tribolium castaneum on treated half of filter paper exposed to various plant extracts and their doses [(a) $20 \mathrm{ml}$, (b) $40 \mathrm{ml}$, (c) $60 \mathrm{ml}$, (d) $80 \mathrm{ml}]$ and control half of filter paper at different exposure intervals.

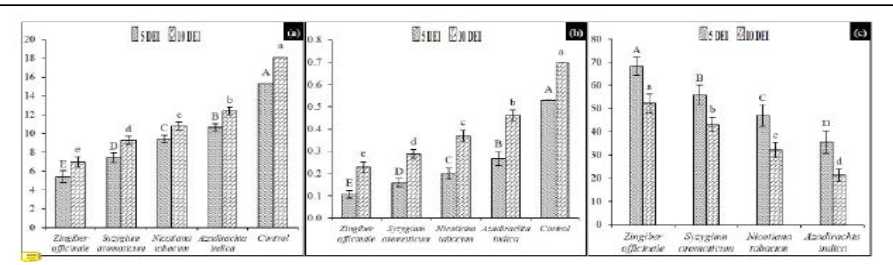

Figure 4: Grain damage (\%) $)^{(\mathrm{a})}$, Grain weight loss $(\%)^{(b)}$ and Feeding Deterrence Index (\%) $)^{(\mathrm{c})}$ (Mean $\pm \mathrm{SE}, n=3)$ due to Tribolium castaneum exposed to various crude plant extracts (Zingiber officinale, Syzygium aromaticum, Nicotiana tabacum and Azadirachta indica) at different exposure intervals. Plant extracts are on $x$-axis and measured variables are on $y$-axis. DEI = Days exposure interval; Means with different letters are significantly different $(P$ $<0.05)$, Bonferroni test, comparisons across all treatments.

Grain weight loss (\%): The main effects and interaction of various crude plant extracts and their doses are highly significant $(P<0.05)$ on percent grain weight loss due to the feeding of $T$. castaneum at two different exposure intervals (Table 1). Percent grain weight loss due to the feeding of $T$. castaneum exposed to different crude extracts mixed in wheat grains was gradually increased as the exposure interval increased. The highest and lowest grain weight loss $(0.462 \pm 0.024 \%$ and $0.230 \pm 0.024 \%)$ was recorded in $A$. indica and $Z$. officinale treated wheat after $10 \mathrm{DEI}$, respectively, while grain weight loss in control treatment ranged from 0.528-0.697\% at both exposure intervals. T. castaneum exposed to different crude extracts caused grain weight loss with the trend of $A$. indica $<N$. tabacum $<S$. aromaticum < Z. officinale (Figure 4). Grain weight loss due to the feeding of T. castaneum decreased as the dose rate of crude plant extracts increased. The lowest dose $(20 \mathrm{mg}$ per $7.5 \mathrm{~g}$ wheat) and highest dose $(80 \mathrm{mg}$ per $7.5 \mathrm{~g}$ wheat) of crude extracts caused $0.493 \pm 0.029 \%$ and $0.319 \pm 0.046 \%$ grain weight loss, respectively after 10 DEI. Doses of crude extracts caused grain weight loss with a trend of $20 \mathrm{mg}$ per $7.5 \mathrm{~g}$ wheat $<40 \mathrm{mg}$ per $7.5 \mathrm{~g}$ wheat $<60 \mathrm{mg}$ per $7.5 \mathrm{~g}$ wheat $<80 \mathrm{mg}$ per $7.5 \mathrm{~g}$ wheat (Figure 5). Percent grain weight loss due to feeding of T. castaneum exposed to different doses $(20-80 \mathrm{mg}$ per $7.5 \mathrm{~g}$ wheat) of $A$. indica treated wheat grains decreased from $0.427-0.151 \%$ at 5 DEI and 0.568 $0.346 \%$ at 10 DEI, $N$. tabacum treated wheat grains decreased from $0.340-0.110 \%$ at 5 DEI and $0.482-$ $0.245 \%$ at $10 \mathrm{DEI}$, S. aromaticum treated wheat grains decreased from $0.256-0.084 \%$ at 5 DEI and $0.381-$ $0.192 \%$ at 10

Journal of Innovative Sciences

June 2020 | Volume 6| Issue 1 | Page 6 
Table 3: Grain damage (\%), Grain weight loss (\%) and Feeding Deterrence Index (\%) (Mean \pm SE, $n=3$ ) exposed to various crude plant extracts and their doses mixed in wheat grains in the presence of Tribolium castaneum at different exposure intervals.

\begin{tabular}{|c|c|c|c|c|c|c|c|}
\hline \multirow{2}{*}{$\begin{array}{l}\text { Plant } \\
\text { extracts }\end{array}$} & \multicolumn{3}{|c|}{ Doses (mg per Grain damage (\%) } & \multicolumn{2}{|c|}{ Grain weight loss (\%) } & \multicolumn{2}{|c|}{ Feeding deterrence index (\%) } \\
\hline & & $5 \mathrm{DEI}$ & $10 \mathrm{DEI}$ & $5 \mathrm{DEI}$ & $10 \mathrm{DEI}$ & $5 \mathrm{DEI}$ & $10 \mathrm{DEI}$ \\
\hline \multirow{4}{*}{$\begin{array}{l}\text { Zingiber } \\
\text { officinale }\end{array}$} & 20 & $8.27 \pm 0.42 \mathrm{GH}$ & $9.87 \pm 0.36 \mathrm{ef}$ & $0.184 \pm 0.014 \mathrm{FG}$ & $0.335 \pm 0.018 \mathrm{ef}$ & $48.94 \pm 1.45 \mathrm{EF}$ & $35.45 \pm 0.95 \mathrm{efg}$ \\
\hline & 40 & $6.53 \pm 0.36 \mathrm{I}$ & $7.60 \pm 0.47 \mathrm{~h}$ & $0.119 \pm 0.013 \mathrm{GHI}$ & $0.270 \pm 0.018 \mathrm{gh}$ & $64.34 \pm 2.14 \mathrm{BCD}$ & $44.80 \pm 1.36 \mathrm{cde}$ \\
\hline & 60 & $4.40 \pm 0.31 \mathrm{~J}$ & $5.60 \pm 0.31 \mathrm{i}$ & $0.084 \pm 0.011 \mathrm{IJ}$ & $0.203 \pm 0.019 \mathrm{i}$ & $73.76 \pm 2.23 \mathrm{~B}$ & $55.98 \pm 2.22 \mathrm{bc}$ \\
\hline & 80 & $2.53 \pm 0.16 \mathrm{~K}$ & $4.93 \pm 0.36 \mathrm{i}$ & $0.041 \pm 0.007 \mathrm{~J}$ & $0.113 \pm 0.015 \mathrm{j}$ & $86.48 \pm 1.83 \mathrm{~A}$ & $73.33 \pm 2.43 a$ \\
\hline \multirow{4}{*}{$\begin{array}{l}\text { Syzyg- } \\
\text { ium } \\
\text { aromati- } \\
\text { cum }\end{array}$} & 20 & $9.60 \pm 0.31 \mathrm{EF}$ & $11.60 \pm 0.41 \mathrm{~d}$ & $0.256 \pm 0.018 \mathrm{DE}$ & $0.381 \pm 0.014 \mathrm{de}$ & $35.43 \pm 1.27 \mathrm{GH}$ & $29.28 \pm 0.24$ fgh \\
\hline & 40 & $8.13 \pm 0.42 \mathrm{GH}$ & $9.60 \pm 0.47 \mathrm{ef}$ & $0.175 \pm 0.016 \mathrm{FGH}$ & $0.315 \pm 0.022 \mathrm{fg}$ & $51.33 \pm 1.91 \mathrm{EF}$ & $38.49 \pm 1.59 \mathrm{def}$ \\
\hline & 60 & $6.93 \pm 0.36 \mathrm{I}$ & $8.67 \pm 0.36 \mathrm{~g}$ & $0.120 \pm 0.008 \mathrm{GHI}$ & $0.263 \pm 0.020 \mathrm{gh}$ & $63.45 \pm 1.09 \mathrm{BCD}$ & $45.97 \pm 1.67 \mathrm{cde}$ \\
\hline & 80 & $5.07 \pm 0.16 \mathrm{~J}$ & $7.33 \pm 0.32 \mathrm{~h}$ & $0.084 \pm 0.011 \mathrm{IJ}$ & $0.192 \pm 0.027 \mathrm{i}$ & $73.63 \pm 2.21 \mathrm{~B}$ & $58.77 \pm 3.55 b$ \\
\hline \multirow{4}{*}{$\begin{array}{l}\mathrm{Nico}^{-} \\
\text {tiana } \\
\text { tabacum }\end{array}$} & 20 & $11.20 \pm 0.31 \mathrm{C}$ & $12.67 \pm 0.42 c$ & $0.340 \pm 0.019 \mathrm{C}$ & $0.482 \pm 0.020 c$ & $22.01 \pm 0.78 \mathrm{I}$ & $18.33 \pm 0.33 \mathrm{hij}$ \\
\hline & 40 & $10.13 \pm 0.36 \mathrm{CDE}$ & $11.47 \pm 0.42 \mathrm{~d}$ & $0.208 \pm 0.012 \mathrm{EF}$ & $0.411 \pm 0.025 \mathrm{~d}$ & $43.88 \pm 0.76 \mathrm{FG}$ & $26.36 \pm 1.32$ fghi \\
\hline & 60 & $9.07 \pm 0.36 \mathrm{EFG}$ & $9.87 \pm 0.36 \mathrm{ef}$ & $0.152 \pm 0.010 \mathrm{FGHI}$ & $0.340 \pm 0.024 \mathrm{ef}$ & $55.79 \pm 0.83 \mathrm{CDE}$ & $35.17 \pm 1.65 \mathrm{efg}$ \\
\hline & 80 & & & $0.110 \pm 0.010 \mathrm{HI}$ & & $66.13 \pm 1.45 \mathrm{BC}$ & $48.68 \pm 1.58 \mathrm{bcd}$ \\
\hline \multirow{4}{*}{$\begin{array}{l}\text { Aza- } \\
\text { dirachta } \\
\text { indica }\end{array}$} & 20 & $12.80 \pm 0.47 \mathrm{~B}$ & $14.27 \pm 0.36 b$ & $0.427 \pm 0.018 \mathrm{~B}$ & $0.568 \pm 0.020 \mathrm{~b}$ & $10.57 \pm 0.28 \mathrm{~J}$ & $10.20 \pm 0.10 \mathrm{jk}$ \\
\hline & 40 & $10.80 \pm 0.37 \mathrm{CD}$ & $12.93 \pm 0.36 c$ & $0.284 \pm 0.017 \mathrm{CD}$ & $0.509 \pm 0.028 c$ & $30.45 \pm 0.80 \mathrm{HI}$ & $16.04 \pm 1.18 \mathrm{ij}$ \\
\hline & 60 & $10.00 \pm 0.31 \mathrm{DEF}$ & $12.13 \pm 0.42 \mathrm{~cd}$ & $0.203 \pm 0.014 \mathrm{EF}$ & $0.424 \pm 0.024 \mathrm{~d}$ & $45.14 \pm 1.27 \mathrm{FG}$ & $24.73 \pm 0.99 \mathrm{ghi}$ \\
\hline & 80 & $8.93 \pm 0.32 \mathrm{FG}$ & $10.27 \pm 0.36 \mathrm{e}$ & $0.151 \pm 0.008 \mathrm{FGHI}$ & $0.346 \pm 0.022 \mathrm{ef}$ & $55.66 \pm 0.86 \mathrm{DE}$ & $34.18 \pm 1.34 \mathrm{efg}$ \\
\hline Control & - & $15.33 \pm 0.36 \mathrm{~A}$ & $18.13 \pm 0.42 \mathrm{a}$ & $0.528 \pm 0.023 \mathrm{~A}$ & $0.697 \pm 0.024 \mathrm{a}$ & $0.00 \pm 0.00 \mathrm{~K}$ & $0.00 \pm 0.00 \mathrm{k}$ \\
\hline
\end{tabular}

DEI: Days exposure interval; Means with different letters are significantly different $(P<0.05)$, Bonferroni test, comparisons across all treatments.

DEI, and Z. officinale treated wheat grains decreased from $0.184-0.041 \%$ at $5 \mathrm{DEI}$ and $0.335-0.113 \%$ at 10 DEI (Table 3).

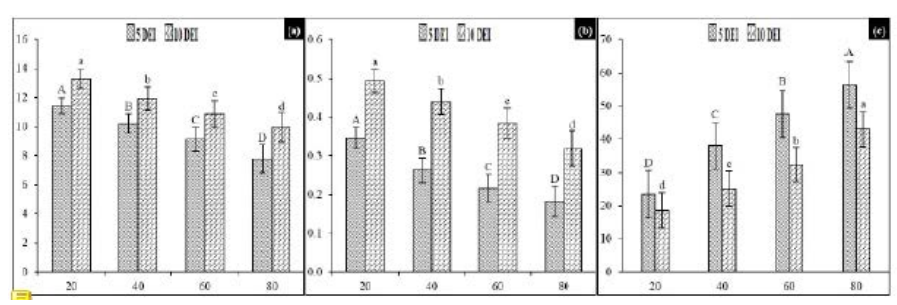

Figure 5: Grain damage (\%) $)^{(\mathrm{a})}$, Grain weight loss (\%) (b) and Feeding Deterrence Index $(\%)^{(\mathrm{c})}($ Mean $\pm \mathrm{SE}$, $n=3)$ due to Tribolium castaneum exposed to various doses $(20 \mathrm{mg}, 40 \mathrm{mg}, 60 \mathrm{mg}$ and $80 \mathrm{mg}$ ) of plant extracts (Zingiber officinale, Syzygium aromaticum, Nicotiana tabacum and Azadirachta indica) at different exposure intervals. Extract doses are on $x$-axis and measured variables are on $y$-axis. DEI $=$ Days exposure interval; Means with different letters are significantly different $(P<0.05)$, Bonferroni test, comparisons across all treatments.

Feeding deterrence index(FDI)(\%): The main effects and interaction of various crude plant extracts and their doses are highly significant $(P<0.05)$ on percent FDI due to T. castaneum at two different exposure intervals (Table 1). Percent FDI due to T. castaneum exposed to different crude extracts mixed in wheat grains was gradually decreased as the exposure interval increased. The highest and lowest FDI $(52.39 \pm 4.07 \%$ and $21.29 \pm$ $2.62 \%)$ was recorded in $Z$. officinale and $A$. indica treated wheat after $10 \mathrm{DEI}$, respectively, while zero FDI in control treatment at both exposure intervals was recorded. T. castaneum exposed to different crude extracts caused FDI with the trend of $Z$. officinale $<S$. aromaticum $<N$. tabacum < A. indica (Figure 4). FDI due to $T$. castaneum increased as the dose rate of crude plant extracts increased. The lowest dose $(20 \mathrm{mg}$ per $7.5 \mathrm{~g}$ wheat) and highest dose (80mg per $7.5 \mathrm{~g}$ wheat) of crude extracts caused $18.65 \pm 2.85 \%$ and $43.00 \pm$ $5.59 \%$ FDI, respectively after 10 DEI. Doses of crude extracts caused FDI with the trend of $80 \mathrm{mg}$ per $7.5 \mathrm{~g}$ wheat $<60 \mathrm{mg}$ per $7.5 \mathrm{~g}$ wheat $<40 \mathrm{mg}$ per $7.5 \mathrm{~g}$ wheat $<20 \mathrm{mg}$ per $7.5 \mathrm{~g}$ wheat (Figure 5). Percent FDI due to T. castaneum exposed to different doses (20-80mg per $7.5 \mathrm{~g}$ wheat) of $Z$. officinale treated wheat grains ranged from $48.94-86.48 \%$ at $5 \mathrm{DEI}$ and $35.45-73.33 \%$ at 10 DEI, $S$. aromaticum treated wheat grains ranged from $35.43-73.63 \%$ at $5 \mathrm{DEI}$ and $29.28-58.77 \%$ at $10 \mathrm{DEI}$, N. tabacum treated wheat grains ranged from 22.01- 
$66.13 \%$ at 5 DEI and $18.33-48.68 \%$ at $10 \mathrm{DEI}$, and $A$. indica treated wheat grains ranged from $10.57-55.66 \%$ at $5 \mathrm{DEI}$ and $10.20-34.18 \%$ at $10 \mathrm{DEI}$ (Table 3).

Results of the present study have revealed that natural plant extracts have the potential to control T. castaneum population in stored wheat. Z. officinale has proved to be effective against the $T$. castaneum as compare to other tested plant extracts, which have more toxic and repellent characteristics, results in less wheat grain damage due to $T$. castaneum. These findings are in accordance with the earlier studies where $Z$. officinale has been proved to be an effective natural insecticidal against $T$. castaneum (Epidi and Odili, 2009; Chaubey, 2011). Ahmad et al. (2019) reported that $Z$. officinale found more effective against $T$. castaneum which result in 15 times higher mortality of adults and 4-5 times reduction in rice grain weight losses due to this insect pest.

Several plant species produce numerous chemical compounds that could be repellent or deterrent or even toxic for insect pests. Some of these compounds are also toxic to the plant itself, and consequently, they are stored in special organs such as flowers and seeds. These chemicals are aimed directly against plant-feeding insect pests (Shojaaddini et al., 2008). Few species of Zingiberaceae plants have been used for medicinal purposes and some species have been reported to have biologically active compounds (Grainge and Ahmed, 1987; Ohsawa et al., 1994).

Z. officinale contains a sesquiterpenes hydrocarbon; and the pungent odor appears to be responsible for its toxic and repellent effect on the insect pests (Purseglove, 1972). Many reports have been published on the insecticidal activity of the essential oils and other products from Zingiber species (Nugroho et al., 1996; Agarwal et al., 2001; Zhang et al., 2004; Owolabi et al., 2009). Anti-feedant and insect growth disruption activity of crude $Z$. officinale extractives have been already reported against the larvae of Spodoptera litura (Sahayaraj, 1998). Z. officinale oil or extract repels the Myzus persicae (Hori, 1999); Bemisia argentifolii (Zhang et al., 2004), Sitophilus zeamais (Ukeh et al., 2009). Z. officinale oil also has insect growth regulatory and antifeedant activity against larvae of the arctiid Spilosoma oblique (Agarwal et al., 2001).

\section{Conclusions and Recommendations}

Fumigants are being widely used management tactics Journal of Innovative Sciences

June 2020 | Volume 6| Issue 1 | Page 8 to rid of the insect pests related issues in stored products which also are responsible for ecological and medical issues due to persistent of toxicity in the environment as well as in the grains as carcinogenic and teratogenic. So, natural plant extracts are the alternatives for said issues. Control of $T$. castaneum with plant extracts is readily available, affordable, less toxic to mammals and safe to the environment. The results of present study indicated that $Z$. officinale is an effective natural plant for the management of $T$. castaneum.

\section{Authors' Contributions}

BA, MR and AMS conceptualized the study; BA and $B$ recorded the data; AMS, MuhammadS and MDG statistical analyzed the data; MR, FA and MehranS wrote Introduction section of the manuscript; BA, $\mathrm{B}, \mathrm{FA}$ and MehranS wrote methodology section of the manuscript; BA, MR and MDG wrote Results and Discussion section of the manuscript; BA edited the format of the graphs and Tables according to the format of this journal; AMS, MuhammadS and MDG reviewed the manuscript and gave suggestions and comments for its improvement. The final manuscript was ultimately perused, scrutinized and approved for final submission by all the authors.

\section{Conflict of interest}

The authors declare that there is no conflict of interest regarding the publication of this article.

\section{References}

Abdullahi, G., Muhamad, R., Dzolkhifli, O. and Sinniah, U.R., 2018. Damage potential of Tribolium castaneum (Herbst) (Coleoptera: Tenebrionidae) on cocoa beans: Effect of initial adult population density and post infestation storage time. Journal of Stored Products Research. 75: 1-9. https://doi.org/10.1016/j. jspr.2017.11.001

Adams, J.M. and Schulten, G.G.M., 1978. Losses caused by insect mites and microorganisms. In: Harris, K.L. and Lindblad. Post-harvest grain loss assessment methods: a manual of methods for the evaluation of post-harvest losses. England: American Association of Cereal Chemist. pp. 83-99. Agarwal, M., Walia, S., Dhingra, S. and Khambay, B.P.S.,2001.Insectgrowthinhibition, antifeedant and antifungal activity of compounds isolated/ 
derived from Zingiber officinale Roscoe (ginger) rhizomes. Pest Management Science. 57(3): 289300. https://doi.org/10.1002/ps.263

Ahmad, F., Iqbal, N., Zaka, S.M., Qureshi, M.K., Saeed, Q. Khan, K.A., Ghramh, H.A., Ansari, M.J., Jaleel, W., Aasim, M. and Awar, M.B., 2019. Comparative insecticidal activity of different plant materials from six common plant species against Tribolium castaneum (Herbst) (Coleoptera: Tenebrionidae). Saudi Journal of Biological Sciences. 26(7): 1804-1808. https://doi. org/10.1016/j.sjbs.2018.02.018

Amin, R., Mondol, R., Rahman, F., Alam, J., Habib, R. and Hossain, T., 2012. Evaluation of insecticidal activity of three plant extracts against adult Tribolium castaneum (Herbst). Biologija. 58(2): 37-41. https://doi.org/10.6001/biologija. v58i2.2484

Aslam, M., Khan, K.A. and Bajwa, M.Z.H., 2002. Potency of some spices against Callosobruchus chinensis L. Journal of Biological Sciences. 2: 449452. https://doi.org/10.3923/jbs.2002.449.452

Atta, B., Rizwan, M., Sabir, A.M., Gogi, M.D. and Ali, K., 2020. Damage potential of Tribolium castaneum (Herbst) (Coleoptera: Tenebrionidae) on wheat grains stored in hermetic and nonhermetic storage bags. International Journal of Tropical Insect Science. 40: 27-37. https://doi. org/10.1007/s42690-019-00047-0

Atta, B., Rizwan, M., Sabir, A.M., Gogi, M.D., Farooq, M.A. and Batta, Y., 2019. Efficacy of entomopathogenic fungi against Brown planthopper Nilaparvata lugens (Stål) (Homoptera: Delphacidae) under controlled conditions. Gesunde Pfanzen. pp. 1-12. https:// doi.org/10.1007/s10343-019-00490-6

Ayub, M.A., Atta, B., Gogi, M.D., Hussain, D. and Ayub, M.M. 2019a. Compatibility of entomopathogenic fungi and plant extracts against the cotton jassid, Amrasca biguttula biguttula Ishid (Homoptera: Cicadellidae). International Entomological Congress, Department of Entomology, University of Agriculture, Faisalabad, Pakistan. pp. 46.

Ayub, M.A., Hussain, D., Atta, B., Gogi, M.D. and Ayub, M.M., 2019b. Use of entomopathogenic fungi against Bemisia tabaci Gennadius (Homoptera: Aleyrodidae) under controlled conditions. International Entomological Congress, Department of Entomology, University of Agriculture, Faisalabad, Pakistan. pp. 46.
Ayub, M.A., Hussain, D., Hafeez, F., Ali, I., Atta, B., Maan, N.A. and Gogi, M.D., 2019c. Management of cotton jassid Amrasca biguttula biguttula Ishid (Homoptera: Cicadelidae) with natural biological alternative (entomopathogenic fungi and plant extracts). $6^{\text {th }}$ International Conference on "Sustainable Agriculture in Changing Climate: Strategies and Management". Facility of Agriculture, University of Poonch, Rawalakot, Azad Jammu and Kashmir, Pakistan. pp. 131-132.

Brari, J. and Kumar, V., 2019. Antifeedant activity of four plant essential oils against major stored product insect pests. International Journal of Pure and Applied Zoology. 7(3): 41-45.

Campbell, J.F. and Runnion, C., 2003. Patch exploitation by female red flour beetle, Tribolium castaneum. Journal of Insect Science. 3: 20-24. https://doi.org/10.1673/031.003.2001

Chaubey, M.K., 2011. Insecticidal Properties of Zingiber officinale and Piper cubeba Essential Oils Against Tribolium castaneum Herbst (Coleoptera: Tenebrionidae). Journal of Biologically Active Products from Nature. 1(5-6): 306-313. https:// doi.org/10.1080/22311866.2011.10719098

Epidi, T.T. and Odili, E.O., 2009. Biocidal activity of selected plant powders against Tribolium castaneum Herbst in stored groundnut (Arachis bypogaea L.). African Journal of Environmental Science and Technology.3(1):1-5.

Fields, P.G., 2006. Effect of Pisum sativum fractions on the mortality and progeny production of nine stored-grain beetles. Journal of Stored Products Research. 42: 86-96. https://doi.org/10.1016/j. jspr.2004.11.005

Gillenwater, H.B. and Mc Donald, L.L., 1975. Repellency of nineteen candidate compounds to adult Tribolium confusum. Journal of the Georgia Entomological Society. 10: 151-155.

Grainge, M. and Ahmed, S., 1987. Handbook of plants with pest control properties. John Wiley and Sons, New York, USA. pp. 470.

Gupta, M.P. and Pathak, R.K., 2009. Bioefficacy of neem products and insecticides against the incidence of whitefly, yellow mosaic virus and pod borer in black gram. Natural Product Radiance. 8(2): 133-136.

Haq, T., Usmani, N.F. and Abbas, T., 2005. Screening of plant leaves as grain protectants against Tribolium castaneum during storage. Pakistan Journal of Botany. 37: 149-153.

Henderson, C.F. and Tilton, E.W., 1995. Tests 
with acaricides against the brown wheat mites. Journal of Economic Entomology. 48(2): 157-161. https://doi.org/10.1093/jee/48.2.157

Hori, M., 1999. The effects of rosemary and ginger oils on the alighting behavior of Myzus persicae (Sulzer) (Homoptera, Aphididae) and on the incidence of yellow spotted streak. Applied Entomology and Zoology. 34: 351-358. https:// doi.org/10.1303/aez.34.351

Khattach, S.U. and Hameed, M., 1986. Control of pulse beetle, Callosobruchus chinensis L. by gamma radiation, irradiated as unmated adults. Bangladesh Journal of Zoology. 14: 167-169.

Madkour, M.H., Zaitoun, A.A. and Singer, F.A., 2012. Efficacy of three plant species extracts in the control of Trogoderma granarium Everts (Coleoptera: Dermestidae). Journal of Food Agriculture and Environment. 10: 1200-1203.

Mamun, M.S.A., Shahjahan, M. and Ahmad, M., 2009. Laboratory evaluation of some indigenous plant extracts as toxicants against red flour beetle, Tribolium castaneum (Herbst). Journal of Bangladesh Agricultural University. 7: 1-5. https://doi.org/10.3329/jbau.v7i1.4789

Morgan, T.D, Baker, P., Kramer, K.J., Basibuyuk, H.H. and Quicke, D.L., 2003. Metals in mandibles of stored product insects: do zinc and manganese enhance the ability of larvae to infest seeds? Journal of Stored Products Research. 39(1): 65-75. https://doi.org/10.1016/S0022474X(02)00019-X

Naseri, B., Borzoui, E., Majd, S. and Mansouri, S.M., 2017. Influence of different food commodities on life history, feeding efficiency, and digestive enzymatic activity of Tribolium castaneum (Coleoptera: Tenebrionidae). Journal of Economic Entomology. 110(5): 2263-2268. https://doi. org/10.1093/jee/tox236

Neoliya, N.K., Singh, D. and Sangwan, R.S. 2007. Azadirachtin-basedinsecticides induce alteration in Helicoverpa armigera Hub. Head polypeptides. Current Science. 92: 94-98.

Nugroho, B.W., Schwarz, B., Wray, V. and Proksch, P., 1996. Insecticidal constituents from rhizomes of Zingiber cassumunar and Kaempferia rotunda. Phytochemistry. 41(1): 129-132. https://doi. org/10.1016/0031-9422(95)00454-8

Ohsawa,K., Riyanto,S.,Honda,H. and Yamamoto,I., 1994. Insecticidal substance from Zingiberaceae. In abstracts, $8^{\text {th }}$ International Congress of Pesticide Chemistry, Washington, USA.
Owolabi, M.S., Oladimeji, M.O., Lajide, L. Singh, G., Marimuthu, P. and Isidorov, V.A., 2009. Bioactivity of three plant derived essential oils against the maize weevils Sitophilus zeamais (Motschulsky) and cowpea weevils Callosobruchus maculates (Fabricius). Electronic Journal of Environmental, Agricultural and Food Chemistry. 8(9): 828-835.

Perez-Mendoza, J., Campbell, J.F. and Throne, J.E., 2014. Effect of abiotic factors on initiation of red flour beetle (Coleoptera: Tenebrionidae) flight. Journal of Economic Entomology. 107(1): 469-472. https://doi.org/10.1603/EC13364

Pires, E.M., Souza, E.Q. Nogueira, R.M., Soares, M.A., Dias, T.K.R. and Oliveira, M.A., 2017. Damage caused by Tribolium castaneum (Coleoptera: Tenebrionidae) in stored Brazil nut. Scientific Electronic Archives. 10: 1-5.

Pretheep-Kumar, P., Mohan, S. and Ramaraju, K., 2007.Long-term efficacy of protein-enriched pea flour against Tribolium castaneum (Coleoptera: Tenebrionidae) in wheat flour. Journal of Central European Agriculture. 7(4): 779-784.

Purseglove,J.W.,1972.Tropicalcrops; Monocotyledons Vol. 2 Longman group Ltd. London. pp. 633.

Qasim,M.U., Muhammad,W.H.,Jin-Jun,W., Jamil, M. and Iqbal,J., 2013. Management of Tribolium castaneum (Coleoptera: Tenebrionidae) with phosphine fumigation in relation to packaging materials and food types. Pakistan Journal of Zoology. 45(6): 1639-1645.

Rahman, M.M., Islam, W. and Ahmed, K.N., 2009. Functional response of the predator Xylocoris flavipes to three stored product insect pests. International Journal of Agriculture and Biology. 11: 316-320.

Rizwan, M., Atta, B., Rizwan, M., Sabir, A.M., Shah, Z.U. and Hussain, M., 2019a. Effect of the entomopathogenic fungus, Beauveria bassiana, combined with diatomaceous earth on the red flour beetle, Tribolium castaneum (Herbst) (Tenebrionidae: Coleoptera). Egyptian Journal of Biological Pest Control. 29: 27. https:// doi.org/10.1186/s41938-019-0131-y

Rizwan, M., Atta, B., Sabir, A.M. and Sabar, M., 2019b. Evaluation of hermetic storage bag under different environmental conditions against biotic and abiotic stresses. $2^{\text {nd }}$ International Conference on Applied Zoology at Government College University, Faisalabad, Pakistan, P-77/ No. 171.

Rizwan, M., Atta, B., Sabir, A.M., Shah, Z.U.,

Journal of Innovative Sciences

June 2020 | Volume 6| Issue 1 | Page 10 
Khalid, U.B. and Ali, Q. 2019c. Efficacy of different storage materials for management of stored product insect pests Tribolium castaneum (Herbst) (Coleoptera: Tenebrionidae), Sitophilus granaries (Coleoptera: Curculionidae) and Sitophilus oryzae (Coleoptera: Curculionidae) for wheat under farm storage conditions. International Entomological Congress, Department of Entomology, University of Agriculture, Faisalabad, Pakistan. pp. 144.

Rizwan, M., Atta, B., Sabir, A.M., Yaqub, M. and Qadir, A., 2019d. Evaluation of the entomopathogenic fungi as a non-traditional control of the Rice leaf roller, Cnaphalocrocis medinalis (Guenee) (Lepidoptera: Pyralidae) under controlled conditions. Egyptian Journal of Biological Pest Control. 29: 10. https://doi. org/10.1186/s41938-019-0111-2

Safavi, S.A. and Mobki, M., 2012. Fumigant toxicity of essential oils from Citrus reticulata Blanco fruit peels against Tribolium castaneum Herbst (Coleoptera: Tenebrionidae). Journal of Crop Protection. 1(2): 115-120.

Sahayaraj, K., 1998. Antifeedant effect of some plant extracts on the Asian armyworm, Spodoptera litura (Fabricius). Current Science. 74: 523-525.

Sami, A.J., Bilal, S., Khalid, M., Nazir, M.T. and Shakoori, A.R., 2018. A Comparative Study of Inhibitory Properties of Saponins (derived from Azadirachta indica) for Acetylcholinesterase of Tribolium castaneum and Apis mellifera. Pakistan Journal of Zoology. 50(2): 725-733. https://doi. org/10.17582/journal.pjz/2018.50.2.725.733

Sankari, S.A. and Narayanswamy, P., 2007. Bioefficacy of flyash-based herbal pesticides against pests of rice and vegetables. Current Science. 92:811-815.

Sarwar, M., 2015. Protecting dried fruits and vegetables against insect pests invasions during drying and storage. American Journal of Marketing Research. 1(3): 142-149.

Shafique, M., Ahmad, M. and Chaudry, M.A., 2006. Feeding preference and development of Tribolium castaneum (Herbst.) in wheat products. Pakistan Journal of Zoology. 38(1): 27-31.

Shojaaddini, M., Moharramipour, S. and Sahaf, B.Z., 2008. Fumigant toxicity of essential oil from Carum copticum against Indian meal moth, Plodia interpunctella. Journal of Plant Protection Research. 48(4): 411-419. https://doi. org/10.2478/v10045-008-0050-5
Singh, R.K. and Singh, A.K., 2005. Efficacy of different indigenous plant products as grain protectants against Rhyzopertha dominica Fabr. on wheat. Indian Journal of Entomology. 67: 196198.

Tapondjou, L.A., Adler, C., Bouda, H. and Fontem, D.A., 2002. Efficacy of powder and essential oil from Chenopodium ambrosioides leaves as post-harvest grain protectants against sixstored product beetles. Journal of Stored Products Research. 38: 395-402. https://doi.org/10.1016/ S0022-474X(01)00044-3

Tembo, Y., Mkindi, A.G., Mkenda, P.A., Mpumi, N., Mwanauta, R., Stevenson, P.C., Ndakidemi, P.A. and Belmain, S.R., 2018. Pesticidal plant extracts improve yield and reduce insect pests on legume crops without harming beneficial arthropods. Frontiers in Plant Science. 9: 1425. https://doi.org/10.3389/fpls.2018.01425

Tripathi, A.K., Singh, A.K. and Upadhyay, S., 2009. Contact and fumigant toxicity of some common spices against the storage insects Callosobruchus maculatus (Coleoptera:Bruchidae) and Tribolium castaneum (Coleoptera: Tenebrionidae). International Journal of Tropical Insect Science. 29(3): 151-157. https://doi.org/10.1017/ S174275840999018X

Udo, I.O., 2005. Evaluation of the potential of some local spices as stored grain protectants against the maize weevil Sitophilus zeamais Mots (Coleoptera: Curculionidae). Journal of Applied Sciences and Environmental Management. 9: 165168.

Ukeh, D.A., Birkett, M.A., Pickett, J.A., Bowman, A.S., Luntz, A.J.M., 2009. Repellent activity of alligator pepper, Aframomum melegueta, and ginger, Zingiber ofûcinale, against the maize weevil, Sitophilus zeamais. Phytochemistry. 70: 751-758. https://doi.org/10.1016/j. phytochem.2009.03.012

Zhang,W.,McAuslane,H.J.and Schuster,D.J.,2004. Repellency of Ginger oil to Bemisia argentifolii (Homoptera: Aleyrodidae) on Tomato. Journal of Economic Entomology. 97(4): 1310-1318. https:// doi.org/10.1093/jee/97.4.1310

Zhang,W.,McAuslane, H.J. and Schuster,D.J. 2004. Repellency of Ginger oil to Bemisia argentifolii (Homoptera: Aleyrodidae) on Tomato. Journal of Economic Entomology. 97(4): 1310-1318. https:// doi.org/10.1093/jee/97.4.1310 